\title{
Topics in Biogeochemistry, Paleoceanography and Paleoclimate
}

Austral Summer Institute, Dichato, Chile, 5 - 30 January 2004

Dichato, a small fishing cove and summer resort in central Chile, was invaded by local and international oceanographers from 5-30 January 2004. A total of 24 participants and seven instructors passed through the seaside village in connection with the fourth annual Austral Summer Institute (ASI), hosted by the Universidad de Concepción at its Marine Biology Station.

The ASI series began in 2001 as part of a cooperative agreement between the Universidad de Concepción, Woods Hole Oceanographic Institution, and the Fundación Andes. Additional funding from PAGES and POGO helped defray costs for ASI-4 participants traveling from Brazil and Colombia.

After a rather hectic opening day, instructors and participants settled quickly into the communal bilingual life structured for ASI-4 by coordinators Carina Lange and Silvio Pantoja, Universidad de Concepción. For four weeks, a core group of 10 participants lived in several cabins, hosting new participants and bidding farewell to others on a weekly basis.

In accordance with the ASI philosophy that learning takes place outside as well as inside the formal classroom-a philosophy deeply appreciated by both participants and instructors-ASI-4 instructors also stayed on site. The interaction between the students, mostly Latin American, and the teachers, some of the most prominent figures in paleoclimate and biogeochemistry, was one of the best results of this summer school. Participants and instructors shared class time as well as many incidents of daily life; opportunities to interact abounded.

ASI-4's first cycle featured Anthony Rathburn (Indiana State University) on "Marine productivity and seasonality: Responses of microbenthos in oxygen-poor environments, past and present" and Lloyd Keigwin (Woods Hole Oceanographic Institution; WHOI) on "Topics in Quaternary ocean and climate change". Cycle

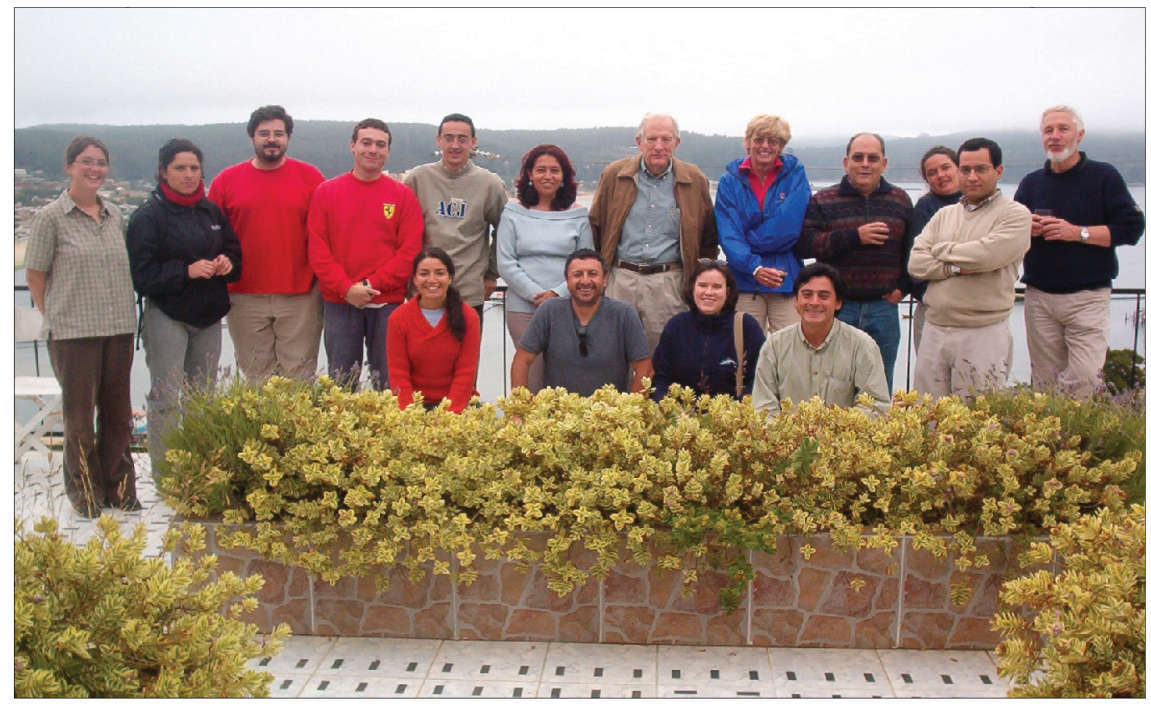

Fig. 1: Participants of the ASI - Workshop in Dichato, Chile.

two brought a highly coordinated unit, with John M. Hayes (WHOI) teaching "Isotope Biogeochemistry" and Jürgen Rullkötter (University of Oldenburg) presenting "Molecular organic geochemistry".

During the third cycle, Jennifer Pike (Cardiff University) worked with “Quaternary ocean and climate history from laminated marine sediments", and Daniel Repeta (WHOI) with "Organic compounds as tracers for paleoclimate". ASI-4 participants were also treated to a special talk by Jeremy Jackson (Scripps Institution of Oceanography) on "Caribbean marine extinctions on different timescales: the changing roles of geology, climate and people".

The final cycle was led by Robert Dunbar (Stanford University), who took an in-depth look at "Air-sea interactions and the global carbon cycle: A paleoclimate perspective from the tropics to the poles". The unfortunate postponement of the afternoon session (Christopher Charles, Scripps Institution of Oceanography, "Ocean chemistry and climate change on timescales of decades to millennia") in the end afforded participants much more time for hands-on practice with Ocean Data Viewer technology, a novel experience for many.

Each cycle had its own dynamic and class structures were varied. There was a wide variety of pre- sentations, practical activities, and evaluations offered by the different teachers. Papers were discussed, lab practicals performed, microfossils and thin sections analyzed, ideas and information exchanged, exercises worked out, skills tested, and evaluations given during ASI-4.

At the end of January, the group left Dichato with a comprehensive wealth of new knowledge. The chance to learn from and work sideby-side with top-level investigators resulted in unique learning opportunities for the participants, whose backgrounds ranged from engineering to marine biology. Since the topics presented were highly relevant to a such a widely diverse group, new research horizons were opened up and ideas for future collaborations were explored.

After the success of ASI-4, it seems Dichato can expect another invasion next January. Details of ASI- 5 will be available at www.udec.cl/udecwhoi in July 2004. The ASI-4 picture gallery will be available in April 2004 on the same web page.

Danielle Barriga ${ }^{1}$ and Gladys bernal ${ }^{2}$ 'University of Conception, Chile; barriga@surnet.cl

${ }^{2}$ National University of Colombia, Medellin, Colombia; gbernal@unalmed.edu.co 